\title{
Serum immunoglobulin G4 in Sjögren's syndrome: a pilot study
}

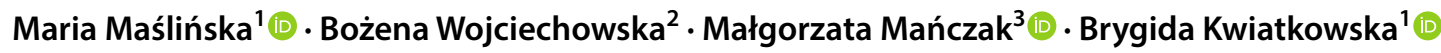

Received: 2 December 2019 / Accepted: 30 January 2020 / Published online: 15 February 2020

(c) The Author(s) 2020

\begin{abstract}
Immunoglobulin IgG4 plays a role in the pathogenesis of the Mikulicz disease previously considered a form of primary Sjögren's syndrome (pSS). We investigated serum levels of IgG4, total IgG, C3, and C4 serum complementary components in patients suspected of Sjögren's syndrome. Basic laboratory and immunological tests, including IgG4 and IgG concentration, were performed on 20 healthy and 68 suspected of pSS individuals. We distinguished: group I: 48 pSS patients; group II (sicca): 20 patients with dryness without pSS. We revealed: statistical differences between groups I and II concerning hypergammaglobulinemia, ESR, RF, ANA, Ro, and La antibodies; lower IgG4 levels and IgG4/IgG ratio in group I compared to healthy individuals ( $p<0.0435 ; 0.0035$, respectively); no significant differences in the concentrations of IgG4 and $\mathrm{IgG} 4 / \mathrm{IgG}$ ratio between sicca and control groups. significantly lower $(p<0.0002) \mathrm{C} 4$ levels in group I compared to other groups; significant differences in $\mathrm{C} 4$ concentration and $\mathrm{IgG} 4 / \mathrm{IgG}$ ratio between three groups $(p=0.0002$ and $p=0.0090$, respectively); a weak negative correlation between $\mathrm{C} 4$ and $\operatorname{IgG}(\mathrm{r}=-0.274)$ in the whole database; weak positive correlation between $\mathrm{C} 4$ and $\mathrm{IgG} 4 / \mathrm{IgG}$ ratio $(r=0.237)$; a negative correlation of $\mathrm{IgG} 4, \mathrm{IgG} 4 / \mathrm{Ig}$ ratio and $\mathrm{C} 4$ with focus score $(\mathrm{r}=-0.281$; $r=-0.327 ; r=-0.406$, respectively). IgG4 serum levels were significantly decreased compared to healthy subjects. IgG4 and C4 levels correlated with infiltrations in minor salivary glands. Hypergammaglobulinemia and decreased serum C4 component levels are typical for pSS.
\end{abstract}

Keywords Immunoglobulin G4 $\cdot \operatorname{IgG} 4 / \mathrm{IgG}$ ratio $\cdot$ Sjögren's syndrome

Maria Maślińska

maslinskam@gmail.com

Bożena Wojciechowska

bozena.wojciechowska@spartanska.pl

Małgorzata Mańczak

m.manczak@op.pl

Brygida Kwiatkowska

kwiatkowskabrygida@gmail.com

1 Clinic of Early Arthritis, National Institute of Geriatrics, Rheumatology and Rehabilitation, Spartańska 1, 02-637 Warsaw, Poland

2 Central Laboratory, National Institute of Geriatrics, Rheumatology and Rehabilitation, Spartańska 1, 02-637 Warsaw, Poland

3 Department of Gerontology, Public Health and Didactics, National Institute of Geriatrics, Rheumatology and Rehabilitation, Spartańska 1, 02-637 Warsaw, Poland

\section{Introduction}

Immunoglobulins (Ig) are proteins whose production depends on the activation and maturation of B cells-associated with the presentation and response to an antigen-as well as on the activation of other cells of the immune system, mainly $\mathrm{T}$ lymphocytes [1]. There are five basic classes of immunoglobulins recognized accordingly to the components of $\mathrm{C}$ domain of heavy chains: $\operatorname{Ig} \mathrm{A}, \operatorname{IgM}$, IgG, $\operatorname{IgE}$, and $\operatorname{IgD}$ [1]. IgG are particularly important for the secondary immune response, especially in the late stage of viral or bacterial infection, and they also play a role in the allergic response. There are four subclasses of IgG: from IgG1 to IgG4. Each subclass has different immune abilities, and impact on the components of the complement as well as each IgG subclass has its specific affinity to $\mathrm{FcR}$ receptors. Immunoglobulin G4 is the least numerous, constituting only about $4 \%$ of total IgG. It does not have the ability to opsonize, does not activate the complement directly, and has an affinity to type I, II FcR receptor [1, 2]. Its role in the immune process is still not fully understood. IgG4 has defined anti-inflammatory 
properties deriving from its ability to inhibit (prevent) the emergence of immune complexes. IgG4 has no impact on the complement activation because of its low affinity to bind Fc $\gamma$ receptors. It presents the highest affinity to Fc $\gamma R$ R, low to Fc $\gamma R$ II, and no affinity to Fc $\gamma$ RIII receptors. IgG4 also acts as an antibody competing with $\mathrm{Ig} \mathrm{E}$ in allergen binding and may also act as a rheumatoid factor (RF).

IgG4 may cause a self-tolerance to allergens together with IL-10 produced by $\mathrm{T}$ and $\mathrm{B}$ regulatory cells [1-3]. The IgG4 immunoglobulin subclass s plays a role not only in allergic diseases, but also in viral infections and parasite infestations and-in the light of current knowledge-in autoimmune diseases. The secretion of IgG4 as IgG2 antibodies is associated with polysaccharide antigens, whereas IgG1 and $\mathrm{IgG} 3$ production is induced in response to protein antigens.

At least some of the autoimmune diseases were related to the IgG4 overproduction by IgG4-positive plasmocytes. During the last 10 years, the criteria for IgG4-Related Diseases (IgG4-RD) diagnosis have been established and their characteristic features have been collected. However, the role of IgG4 immunoglobulin remains still unclear in such intensive inflammation with storiform fibrosis and obstructive phlebitis. Although some researchers concluded that it may be an epiphenomenon, the role of IgtG4 still needs a further research $[4,5]$.

What is interesting, Mikulicz's disease-with its description of salivary gland enlargement and dryness symptomshas been for years considered a picture of primary Sjögren's syndrome (pSS). Currently, its affiliation to IgG4-RD has been confirmed. Thus, the recognition of IgG4-RD redefined the diagnosis of pSS and was the reason that some of the previously established diagnoses were verified.

The pSS is an autoimmune rheumatic disease (ARD) with activation of $\mathrm{B}$ cells leading to hypergammaglobulinemia and with antinuclear autoantibodies'-mainly against ribonucleoproteins (anti-Ro/SS-A, anti-La/SS-B antibodies)_production. The main clinical features of pSS are: mucosal dryness and internal organs involvement with mononuclear cell, including plasmatic cells-infiltrations, located particularly in exocrine glands $[6,7]$. Among the environmental triggering factors, viral infections, especially with Epstein-Barr virus (EBV), play an important role in pSS pathogenesis. This DNA virus from Herpesviridae family targeted exclusively B cells, with predilection to the salivary glands, which may cause symptoms of dryness [8]. EBV has the ability of existing in both, the lytic and the latent phase of the infection. This feature, along with several other mechanisms (e.g., molecular mimicry, T-cell costimulatory gene CD70 overexpression, production of viral IL-10, or possibility for impaired EBV-specific T-cell response) enables it to modulate host response, as well as immunoglobulin and autoantibody production. This, in turn, leads to the development of autoimmunity, and may also lead to the development of malignancies, especially lymphoma [8, 9]. Hypocomplementemia predominantly of $\mathrm{C} 4$ and $\mathrm{C} 3$ component of complement is often found in autoimmune diseases, especially in pSS. Ramos-Casals et al. [10] detected low $\mathrm{C} 4$ in $24 \%(n=81)$ of 355 examined pSS patients, whereas in other study, hypocomplementemia was found in $8 \%$ of pSS patients [11]. Researchers highlighted that low $\mathrm{C} 4$ component of complement is associated with higher risk of lymphoma and increases mortality in pSS [10, $12,13]$. This work was initiated due to the observation in our clinical practice of a decrease of serum IgG4 concentration in patients with pSS.

\section{Objectives}

The aim of the presented pilot observational work was to study serum IgG4 concentration in patients with suspected pSS referred for diagnosis due to the symptoms of dryness and in a group of healthy volunteers - to determine whether the level of IgG4 correlates with basic laboratory and immunological parameters, as well as with the severity of dry eye symptoms, mononuclear cell infiltration in minor salivary gland biopsies, and potential organ involvement.

\section{Materials and methods}

Patients with symptoms of eye and mouth dryness referred to the Early Arthritis Clinic with suspected pSS $(n=68)$ were included in the analysis. The control group consisted of healthy volunteers $(n=20)$. A full diagnostics for pSS was performed, which included basic laboratory tests such as: whole blood count with white blood cells (WBC; count per microliter of blood), erythrocyte sedimentation rate (ESR; $\mathrm{mm} / \mathrm{h}$ ), C-reactive protein (CRP; 0-0.5 mg/L), urine analysis with $\mathrm{pH}$ and urine-specific gravity (USG), as well as immunological tests, such as antinuclear antibodies (ANA) were detected with immunofluorescence (IF) on the cell line HEp-2 (Human Epithelial purpose; HEp-2000), antiRo/SS-A, and anti-La/SS-B antibodies determined by the semi-quantitative method Immunoblot (Anti-ENA Profile Plus, Euroimmun, Germany, DL 1590-1601-1 G; semiquantitative immunoblotting evaluation on a scale from 1 to 3 of the strength of binding of the antibody to the antigen was also performed. Rheumatoid factor (RF; normal range below $34 \mathrm{IU} / \mathrm{mL})$ and serum concentrations of $\mathrm{IgG} 4(\mathrm{mg} /$ $\mathrm{dL}$ ), total $\mathrm{IgG}$ (tIIgG; $\mathrm{mg} / \mathrm{dL}$ ), and $\mathrm{C} 4$ and $\mathrm{C} 3$ complement components were measured by nephelometry. The normal range of IgG4 considered as $800-1400 \mathrm{mg} / \mathrm{dL}$; total IgG normal range $751-1560 \mathrm{mg} / \mathrm{dL}$; $\mathrm{C} 3$ component of complement normal range $79-152 \mathrm{mg} / \mathrm{dL} ; \mathrm{C} 4$ component of complement normal range $16-38 \mathrm{mg} / \mathrm{dL}$ have been adopted for the purpose of this study. Keratoconjunctivitis sicca was confirmed 
by Schirmer's test and Ocular Staining Score (OSS), using lissamine green and fluorescein staining-total OSS scores of 3-12 per eye; focal sialadenitis was confirmed in minor salivary gland biopsy as focus score (FS; defined as the number of infiltrates from mononuclear cell containing at least 50 inflammatory cells in a $4 \mathrm{~mm}^{2}$ of glandular section).

The impact of immunosuppressive drugs on the course of the disease, including the evaluated laboratory parameters, was not analyzed, as the examined patients were referred for diagnosis prior to immunosuppressive therapy.

Informed consent has been obtained from all patients and healthy subjects. The study was approved by the Ethics Committee of NIGRiR.

\section{Statistical analysis}

Statistical analysis was carried out with Statistica13 programme. The normality of continuous variables distribution was verified using the Shapiro-Wilk test. The distribution of all variables analyzed in the study differed significantly from normal distribution; therefore, the median and interquartile range (IQR) were used. Kruskal-Wallis test was used to compare continuous variables in three groups and Mann-Whitney $U$ test was used in two groups. For comparison of nominal variables, Chi-square test or two-tailed Fisher exact test (when the expected values were $<5$ ) were used. Correlations between the variables were examined using Spearman's rank correlation analysis. The statistical significance was established at $p<0.05$.

\section{Results}

In the course of diagnostics, two groups of patients were distinguished: group I consisted of 48 patients with the established diagnosis of pSS (according to 2012 American College of Rheumatology (ACR) and 2016 ACR/European League Against Rheumatism (EULAR) criteria [7, 14]) with mean age of 51 years (IQR: 36-60), 40 female patients [83\%] (F) 8 male patients [17\%] (M); group II of patients the symptoms of eye or/and mouth dryness, but without confirmed pSS confirmation (sicca group) included 20 subjects [mean age of 53 years; IQR: 41-62; 17 [85\%] F, 3 [15\%] M. Group III consisted of 20 healthy subjects [mean age of 46 years; IQR: 44-50; 20 [100\%] F.

The group with confirmed pSS (gr. I) and the group with dryness (gr. II) were compared in terms of basic tests obtained in the diagnosis of Sjögren's syndrome, as presented in Table 1.

The groups differed significantly in terms of gammaglobulin concentration, ESR, RF, ANA antibody titers, and OSS score (higher in the pSS group), as well as in the presence of anti-SS-A and anti-SS-B antibodies. In the pSS group, the Schirmer's test result was significantly lower.

These two groups were also compared in terms of potential organ changes, and the occurrence of polyneuropathy symptoms was significantly more frequent in the pSS group. No central nervous system involvement was found, except for strokes including transient ischemic attack (TIA) history in both groups, regardless of the occurrence of autoimmune disease (Table 2).
Table 1 Comparison between I (pSS) and II (sicca group)

\begin{tabular}{|c|c|c|c|c|c|}
\hline & \multicolumn{2}{|c|}{ pSS group } & \multicolumn{2}{|c|}{ Sicca group } & \multirow[t]{2}{*}{$p$} \\
\hline & $N$ & Median (Q1-Q3) & $N$ & Median (Q1-Q3) & \\
\hline WBC $\left(\times 103\right.$ per $\left.\mathrm{mm}^{3}\right)$ & 48 & $4.81(3.89-6.08)$ & 20 & $4.60(4.37-5.94)$ & 0.899 \\
\hline $\operatorname{ESR}(\mathrm{mm} / \mathrm{h})$ & 48 & $25.5(12.5-35.5)$ & 20 & $11.5(7.5-24.0)$ & 0.042 \\
\hline $\mathrm{CRP}(\mathrm{mg} / \mathrm{dL})$ & 48 & $7.0(5.0-13.0)$ & 20 & $6(3.5-9.0)$ & 0.102 \\
\hline $\mathrm{RF}(\mathrm{IU} / \mathrm{mL})$ & 48 & $35.3(20.0-168)$ & 18 & $20.0(20.0-27.4)$ & 0.015 \\
\hline Schirmer's test (mm) & 48 & $4.00(2.25-13.75)$ & 20 & $12.25(7.75-19.50)$ & 0.001 \\
\hline OSS & 38 & $3.75(2.50-6.50)$ & 11 & $0.50(0.00-2.00)$ & 0.005 \\
\hline $\begin{array}{l}\text { Serum concentration of gammaglob- } \\
\text { ulins }(\mathrm{g} / \mathrm{dL})\end{array}$ & 48 & $1.45(1.22-1.69)$ & 20 & $1.18(1.06-1.41)$ & $\mathbf{0 . 0 1 0}$ \\
\hline Urine $\mathrm{pH}$ & 48 & $6.0(5.0-6.5)$ & 20 & $6.0(5.0-6.5)$ & 0.419 \\
\hline Urine-specific gravity (1010-1030) & 48 & $1014(1010-1020)$ & 20 & $1016(1011-1020)$ & 0.684 \\
\hline Focus score & 47 & $2(1-3)$ & 20 & $0(0-0)$ & $<0.001$ \\
\hline $\ln \mathrm{ANA}$ & 48 & $7.16(5.77-7.85)$ & 20 & $4.73(4.38-5.77)$ & $<0.001$ \\
\hline Anti Ro/SS-A antibodies & 48 & $3(2-3)$ & 20 & $0(0-2)$ & $<0.001$ \\
\hline Anti La/SS-B antibodies & 48 & $1(0-2)$ & 20 & $0(0-0)$ & 0.005 \\
\hline
\end{tabular}

Significant $p$ values are in bold

$W B C$ white blood count, ESR erythrocyte sedimentation rate, $C R P$ C-reactive protein, $R F$ rheumatoid factor, OSS ocular staining score (3-12 per eye), $F S$ focus score (FS $=1 ; 50$ mononuclear cells $/ 4 \mathrm{~mm}^{2}$ of glandular section), InANA natural logarithm—antinuclear antibodies 
Table 2 Comparison between I and II groups in term of organ involvement

\begin{tabular}{|c|c|c|c|c|c|}
\hline & \multicolumn{2}{|c|}{ pSS group } & \multicolumn{2}{|c|}{ Sicca group } & \multirow[t]{2}{*}{$p$} \\
\hline & $N$ & $n(\%)$ & $N$ & $n(\%)$ & \\
\hline Sialadenitis & 48 & $11(23 \%)$ & 20 & $3(15 \%)$ & 0.352 \\
\hline Arthritis & 48 & $9(19 \%)$ & 19 & 0 & 0.052 \\
\hline Arthralgia & 48 & $37(77 \%)$ & 19 & $14(74 \%)$ & 0.760 \\
\hline Interstitial lung changes & 48 & $3(6 \%)$ & 20 & $1(5 \%)$ & 1 \\
\hline Polyneuropathy ${ }^{\mathrm{a}}$ & 48 & $10(21 \%)$ & 20 & 0 & 0.028 \\
\hline Previous brain stroke ${ }^{\mathrm{b}}$ & 48 & $9(19 \%)$ & 20 & $4(20 \%)$ & 1 \\
\hline Hashimoto disease & 46 & $7(15 \%)$ & 20 & $4(20 \%)$ & 0.723 \\
\hline
\end{tabular}

Significant $p$ value is in bold

Fisher's two-sided test

${ }^{\text {a }}$ Confirmed using electromyography

${ }^{\mathrm{b}}$ Brain stroke including TIA in anamnesis without confirmed vasculitis or antiphospholipid syndrome

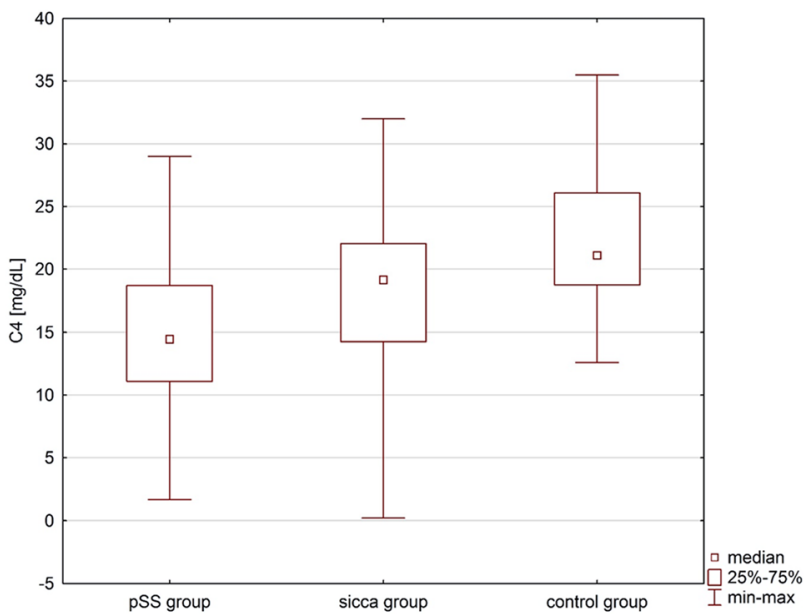

Fig. 1 C4 complement component concentration in the analyzed groups

A group of healthy volunteers were also included in the analysis of $\mathrm{IgG} 4$, total $\mathrm{IgG}$, and $\mathrm{C} 4$ complement components serum level.

In the tests performed, the occurrence of low serum concentration of $\mathrm{C} 4$ complement component in the pSS group was most noticeable. In the pSS group, it was observed in up to $59 \%(n=27)$ of patients versus $30 \%(n=6)$ in the sicca group and $10 \%(n=2)$ in the healthy group. Therefore, $\mathrm{C} 4$ complement component concentration was significantly lower $(p<0.0002)$ in the pSS group in comparison with other studied groups, as shown in Fig. 1 and Table 3.

There were significant differences in $\mathrm{IgG} 4 / \mathrm{IgG}$ ratio between three analyzed groups $(p=0.0090)$. Differences between the pSS group and the control group are responsible for the statistical significance obtained in these comparisons. We also found differences on the verge of statistical significance in $\operatorname{IgG} 4$ and total $\operatorname{IgG}$ between study groups $(p=0.0963$ and $p=0.0793$, respectively). (Table 3).

None of the examined patients had lymphoma during the diagnosis, also among patients with decreased $\mathrm{C} 4$.

After the exclusion of group II (the sicca group) from the initial group of patients suspected of pSS, it was possible to present the differences between the pSS and the healthy group - with statistically significant differences found in the concentration of $\mathrm{C} 4$, IgG4, Ig G, and with IgG4/IgG ratioas presented in Table 4 .

Significantly lower IgG4 serum concentrations and IgG4/ $\mathrm{IgG}$ ratio and higher IgG concentration were observed in the pSS group, compared to the control healthy group.

We found a weak negative correlation between $\mathrm{C} 4$ and IgG4 $(r=-0.274)$ in the whole database (without dividing into groups) and a weak positive correlation between $\mathrm{C} 4$ and $\mathrm{IgG} 4 / \mathrm{IgG}$ ratio $(r=0.237)$.

The lower $\mathrm{C} 4$ complement component concentration was significantly correlated with sialadenitis in the pSS group. Arthritis was confirmed only in $1(4 \%)$ patient and it is difficult to indisputably conclude that there is a significant effect of $\mathrm{C} 4$ decrease on the onset of arthritis. Other correlations with interstitial lung changes, polyneuropathy, or Hashimoto's disease were not found in the analyzed pSS group (Table 5). There were no significant correlations between lowering IgG4 and analyzed organ involvement.

The correlations of $\mathrm{C} 4, \mathrm{IgG} 4$, and $\mathrm{IgG} 4 / \mathrm{IgG}$ ratio with laboratory basic (ESR, CRP, WBC, gammaglobulin concentration, USG, and urine $\mathrm{pH}$ ) and immunological parameters (RF, ANA, Anti SS-A, and anti-SS-B antibodies) as well as with FS, OSS, and the result of the Schirmer's test were assessed. Immunoglobulin G4 serum concentration and $\mathrm{IgG} 4 / \mathrm{IgG}$ ratio, as well as $\mathrm{C} 4$ complement component
Table 3 Comparison between three studied groups in terms of $\mathrm{C} 3, \mathrm{C} 4$ component of complement, IgG4, and IgG concentration and IgG4/IgG ratio

\begin{tabular}{|c|c|c|c|c|c|c|c|}
\hline & \multicolumn{2}{|c|}{ pSS group } & \multicolumn{2}{|c|}{ Sicca group } & \multicolumn{2}{|c|}{ Healthy group } & \multirow[t]{2}{*}{$p$} \\
\hline & $N$ & Median (Q1-Q3) & $N$ & Median (Q1-Q3) & $N$ & Median (Q1-Q3) & \\
\hline C3 & 46 & $94.7(76.8-111,0)$ & 20 & $95.0(84.7-106.0)$ & 20 & $97.6(86.0-109.0)$ & 0.5379 \\
\hline $\mathrm{C} 4$ & 46 & $14.5(11.1-18.7)$ & 20 & $19.2(13.3-22.1)$ & 20 & $21.1(18.8-26.1)$ & 0.0002 \\
\hline IgG4 & 48 & 417 (186-825) & 20 & 599 (313-955) & 20 & $729(293-1575)$ & 0.0963 \\
\hline IgG & 42 & 1435 (1170-1790) & 18 & $1385(1110-1730)$ & 20 & $1260(1085-1350)$ & 0.0793 \\
\hline $\mathrm{IgG} 4 / \mathrm{IgG}$ & 42 & $0.303(0.137-0.554)$ & 18 & $0.424(0.245-0.766)$ & 20 & $0.722(0.281-1.116)$ & 0.0090 \\
\hline
\end{tabular}

Significant $p$ values are in bold 
Table 4 Comparison between pSS and healthy control group in terms of $\mathrm{C} 3, \mathrm{C} 4$ component of complement and $\mathrm{IgG} 4$, IgG serum concentration, and $\mathrm{IgG} 4 / \mathrm{IgG}$ ratio

\begin{tabular}{|c|c|c|c|c|c|}
\hline \multirow[t]{2}{*}{ Parameter } & \multicolumn{2}{|c|}{ Sjögren's syndrome } & \multicolumn{2}{|c|}{ Healthy group } & \multirow[t]{2}{*}{$p$} \\
\hline & $N$ & Median (Q1-Q3) & $N$ & Median (Q1-Q3) & \\
\hline C3 (mg/dL) & 46 & 94.7 (76.8-111.0) & 20 & $97.6(86.0-109.0)$ & 0.2884 \\
\hline $\mathrm{C} 4(\mathrm{mg} / \mathrm{dL})$ & 46 & $14.5(11.1-18.7)$ & 20 & $21.1(18.75-26.1)$ & 0.0000 \\
\hline IgG4 (mg/dL) & 48 & $417(185.5-824.5)$ & 20 & $\begin{array}{l}728.5(292.5- \\
1575)\end{array}$ & 0.0435 \\
\hline $\operatorname{IgG}(\mathrm{mg} / \mathrm{dL})$ & 42 & 1435 (1170-1790) & 20 & $1260(1085-1350)$ & 0.0245 \\
\hline IgG4/IgG & 42 & $\begin{array}{l}0.303(0.137- \\
0.554)\end{array}$ & 20 & $\begin{array}{l}0.722(0.281- \\
1.116)\end{array}$ & 0.0035 \\
\hline
\end{tabular}

Significant $p$ values are in bold

Table 5 Correlations between $\mathrm{C} 4$ serum concentrations and clinical symptoms/organ involvement

\begin{tabular}{|c|c|c|c|c|c|}
\hline \multirow[t]{2}{*}{ Clinical findings } & \multicolumn{2}{|c|}{$\begin{array}{l}\text { Low C4 } \\
(<16 \mathrm{mg} / \mathrm{dL})\end{array}$} & \multicolumn{2}{|c|}{$\begin{array}{l}\mathrm{C} 4 \text { in normal } \\
\text { range }\end{array}$} & \multirow[t]{2}{*}{$p$} \\
\hline & $N$ & $n(\%)$ & $N$ & $n(\%)$ & \\
\hline Sialadenitis & 27 & $10(37 \%)$ & 19 & $1(5 \%)$ & 0.017 \\
\hline Arthritis & 27 & $1(4 \%)$ & 19 & $7(37 \%)$ & 0.006 \\
\hline Arthralgia & 27 & $20(74 \%)$ & 19 & $16(84 \%)$ & 0.488 \\
\hline Interstitial lungs changes & 27 & 0 & 19 & $3(16 \%)$ & 0.064 \\
\hline Polyneuropathy & 27 & $7(26 \%)$ & 19 & $3(16 \%)$ & 0.488 \\
\hline Previous brain stroke & 27 & $4(15 \%)$ & 19 & $5(26 \%)$ & 0.456 \\
\hline Hashimoto's diseases & 26 & $3(12 \%)$ & 18 & $3(17 \%)$ & 0.676 \\
\hline
\end{tabular}

Significant $p$ values are in bold

levels, negatively correlated with focus score $(r=-0.281$; $r=-0.327 ; r=-0.406$, respectively). C4 complement component level and $\mathrm{IgG} 4 / \mathrm{IgG}$ ratio also negatively correlated with ANA ( $r=-0.310 ; r=-0.314$, respectively). The negative correlation between $\mathrm{IgG} 4 / \mathrm{IgG}$ ratio and $\mathrm{RF}$ also was found $(r=-0.261)$. There were no other significant correlations between the studied variables.

\section{Discussion}

In the presented observational study, the comparison between two groups had been planned: the pSS group and healthy volunteers, but in the course of diagnostic procedures additional group emerged-consisting of patients with symptoms of dryness, but not fulfilling the pSS classification criteria. This led to the comparison of the three groups, broadening the previously planned analysis. The comparison between the pSS and the sicca group confirmed the essential features of pSS, such as hypergammaglobulinemia, the presence of ANA antibodies, the presence of anti SS-A, anti SS-B antibodies, a significant decrease in $\mathrm{C} 4$ complement component (up to 59\% in the pSS group), and significantly more frequent occurrence of higher RF and ESR. Also, in the pSS group, typical mononuclear cell infiltrations in minor salivary glands biopsy were observed, fulfilling the focus score criteria and a significant reduction of tears secretion with conjunctival and corneal surface damage assessed by staining and Schirmer's test compared to the sicca group.

The occurrence of organ changes present at the time of the diagnosis was also compared and peripheral polyneuropathy was found only in patients with pSS. There were no significant differences between groups I and II in interstitial changes in the lungs or central nervous system involvement, which may be related to the possible short duration of autoimmune disease, as well as to the relatively small studied group. Hashimoto's disease occurred similarly in both groups of patients in 15\% (the pSS group) and 20\% (the sicca group), which differs slightly from the data described for the general population, which is $10-12 \%$ [15].

We confirmed our clinical observations showing a significant reduction of $\mathrm{IgG} 4$ serum concentration in the pSS group compared to the healthy group ( $p=0.0435)$, as well as a significantly lower $(p=0.0035)$ serum $\operatorname{IgG} 4 /$ total $\operatorname{IgG}$ ratio compared to healthy individuals. The latter phenomenon may be partly associated with hypergammaglobulinemia usually occurring in pSS, but the effect of the observed low IgG4 levels on $\mathrm{IgG} 4 / \mathrm{IgG}$ ratio should be taken into account as well.

Hypergammaglobulinemia was a laboratory parameter significantly differentiating the pSS group from the sicca group $(p=0.010)$; also the pSS group significantly differed from healthy group in terms of IgG concentration $(p=0.0245)$.

Intriguingly, the concentrations of $\mathrm{IgG} 4$ and $\mathrm{IgG} 4$ with respect to the total $\mathrm{IgG}$ in patients with Sjögren's syndrome and in subjects from the dryness group were not statistically different. This finding coincided with the similar activity of Epstein-Barr virus in both the pSS and the sicca group of patients, as well as with the reactivation of this virus infection and the presence of dryness symptoms - a phenomenon presented in our other study [16]. In that study, we presented that the past infection or infection reactivation affects more than $70 \%$ of respondents from these two groups, compared to $30 \%$ from the healthy control group (data not shown) [16].

However, the coincidence of EBV with low IgG4 levels in group I would contradict observations presented in the work of Nagata et al. [17] in which the authors suggested that EBV-affected lymphocytes are stimulated to produce IgG4. It should be noted, however, that in the case of this research, the studied subjects were affected by Graves' disease-in which the stimulation of IgG4 production is a separate phenomenon. This may at least partly explain the difference between our work and the said research by Nagata et al. Recently, published papers focus primarily on the possibility 
of linking EBV infection with the development of IgG4related diseases [18]. In view of the observations presented in our study, this topic requires broader exploration.

Since the difference in IgG4 serum concentrations between groups I and II found in our study was on the verge of statistical significance, further study of this variable, performed on a large number of subjects, should be considered. It may lead to more statistically significant results, proving the difference between pSS patients and the dryness group in the above-described respect. The $\mathrm{C} 4$ hypocomplementemia was a laboratory feature clearly distinguishing the pSS group from other groups and occurred in a much larger percentage (59\%) of pSS patients than it is presented in the literature $[10,12]$. Such high result can be associated with a relatively small pSS group. As the main source of complement components are hepatocytes and epithelial cells, which damage the underlying pathogenesis of pSS, leading to a decrease in the complement components such as C4 [19], our finding in this regard was fully expected.

The deficiency of $\mathrm{C} 4$ increases the risk of the development of infections and systemic autoimmune diseases characterized by autoantibodies production, such as Sjögren's syndrome; therefore, the patients with hypocomplementemia need further regular control and screening for lymphoma development.

We found the weak negative correlation $(r=-0.274)$ between $\mathrm{C} 4$ component complement levels and IgG4 due to significant hypocomplementemia in group I. This phenomenon may influence $\mathrm{IgG} 4$ production, but it requires confirmation on a wider group of pSS patients.

The independence of IgG4 from the complement regulation is highlighted as crucial in the properties of this immunoglobulin subclass, although there are reports, that IgG4 immunoglobulin, as well as immune complexes composed of IgG4, may have the ability to influence classical and alternative pathways of complement activation [20]. The $\mathrm{C} 4$ complement component (both $\mathrm{C} 4 \mathrm{~A}$ and $\mathrm{C} 4 \mathrm{~B}$ isoforms) is an essential player in classical complement cascade, which causes the generation of the $\mathrm{C} 3$ convertase, as well as the enhancement of the humoral activity. It plays a role in the immune response as an important factor in the prevention of bacterial infections and the immune complex-mediated autoimmunity activity [21].

In IgG4-RD diseases, hypocomplementemia may also be observed as an expression of immunological and local complement activity, as well as the effect of a generalized autoimmune inflammation [22].

Although our research demonstrates low IgG4 levels in pSS, there were studies [23, 24] showing an increase in IgG4 concentration in patients with pSS comparable to this occurring in IgG4-RD [18]. Mavragani et al. [24] found elevated serum concentrations but only in $7.5 \%$ of the studied pSS patients $(n=133 ; 100 \%)$; however, the authors explained it with the occurrence of features of IgG4 disease such as autoimmune cholangitis and pancreatitis, as well as interstitial nephritis.

In the presented study, lower $\mathrm{C} 4$ complement component levels were associated mainly with sialadenitis in the pSS group, but no such relationship has been demonstrated for IgG4. Both IgG4 and C4 complement component levels correlated negatively with FS. As FS is an indicator of local activation of mononuclear cells and salivary gland inflammation, this may suggest that IgG4 and C4 levels may play a role in this regard-an issue which requires further study. The described results also confirmed the importance of lowering of $\mathrm{C} 4$ concentration for the course of pSS and for both clinical and immunological aspects of disease.

\section{Limitations}

The main limitation of the study, which is an introduction to a planned wider research on a larger cohort of pSS and sicca group patients, is a relatively small size of the studied groups. However, the demonstrated differences between $\mathrm{IgG} 4$ serum concentration, IgG4/total IgG ratio, and $\mathrm{C} 4$ complement levels between patients with pSS and the control group were evident.

\section{Conclusions}

This preliminary study demonstrated a significantly decreased level of IgG4 serum concentrations in patients with pSS compared to healthy subjects.

The obtained results also confirmed, as expected, that the decreased $\mathrm{C} 4$ complement component levels and hypergammaglobulinemia are one of the characteristic laboratory features of pSS.

IgG4 and $\mathrm{C} 4$ serum levels correlated with infiltrations in minor salivary glands defined as the focus score in pSS.

The importance of lowering serum IgG4 concentration in patients with pSS as a laboratory parameter supporting diagnostics in clinical practice requires the extension of the study group.

Funding The presented work was not funded.

\section{Compliance with ethical standards}

Conflict of interest The authors declare no conflict of interest.

Open Access This article is licensed under a Creative Commons Attribution 4.0 International License, which permits use, sharing, adaptation, distribution and reproduction in any medium or format, as long as you give appropriate credit to the original author(s) and the source, provide a link to the Creative Commons licence, and indicate if changes were made. The images or other third party material in this article are 
included in the article's Creative Commons licence, unless indicated otherwise in a credit line to the material. If material is not included in the article's Creative Commons licence and your intended use is not permitted by statutory regulation or exceeds the permitted use, you will need to obtain permission directly from the copyright holder. To view a copy of this licence, visit http://creativecommons.org/licenses/by/4.0/.

\section{References}

1. Schroeder HW, Cavacini L (2010) Structure and function of immunoglobulins. J Allergy Clin Immunol 125(202):S41-S52. https://doi.org/10.1016/j.jaci.2009.09.046

2. Jung S, Schickel JN, Kern A et al (2016) Chronic bacterial infection activates autoreactive B cells and induces isotype switching and autoantigen-driven mutations. Eur J Immunol 46:131-146. https://doi.org/10.1002/eji.201545810

3. Scott-Taylor TH, Axinia SC, Amin S, Pettengell R (2018) Immunoglobulin G; structure and functional implications of different subclass modifications in initiation and resolution of allergy. Immun Inflamm Dis 6(1):13-33. https://doi.org/10.1002/iid3.192

4. Masaki Y, Kurose N, Yamamoto M et al (2012) Cut off values of serum IgG4 and histopathological IgG4+Plasma cells for diagnosis of patients with IgG4-related disease. Int J Rheum. ArticleID:580814, 5 pages. https://doi.org/10.1155/2012/580814

5. Umehara H, Nakajima A, Nakamura T et al (2014) IgG4-related disease and its pathogenesis-cross-talk between innate and acquired immunity. Int Immunol 26(11):585-595. https://doi. org/10.1093/intimm/dxu074

6. Ryu JH, Horie R, Sekiguchi H, Peikert T, Yi ES (2012) Spectrum of disorders associated with elevated serum IgG4 levels encountered in clinical practice. Int J Rheumatol. ArticleID:232960, 6 pages. https://doi.org/10.1155/2012/232960.

7. Shiboski SC, Shiboski CH, Criswell L et al (2012) American College of Rheumatology classification criteria for Sjögren's syndrome: a data-driven, expert consensus approach in the Sjögren's International Collaborative Clinical Alliance cohort. Arthritis Care Res (Hoboken) 64(4):475-487. https://doi.org/10.1002/ acr.21591

8. Maślińska M (2019) The role of Epstein-Barr virus infection in primary Sjögren's syndrome. Curr Opin Rheumatol 31(5):475483. https://doi.org/10.1097/BOR.0000000000000622

9. Alunno A, Leone MC, Giacomelli R, Gerli R, Carubbi F (2018) (2018) Lymphoma and lymphomagenesis in primary Sjögren's syndrome. Front Med (Lausanne) 5:102. https://doi.org/10.3389/ fmed.2018.00102

10. Ramos-Casals M, Brito-Zeron P, Yagüe J et al (2005) Hypocomplementemia as an immunological marker of morbidity and mortality in patients with primary Sjögren's syndrome. Rheumatology 44(1):89-94. https://doi.org/10.1093/rheumatology/keh407

11. García-Carrasco M, Ramos-Casals M, Rosas J et al (2002) Primary Sjögren syndrome: clinical and immunologic disease patterns in a cohort of 400 patients. Medicine (Baltimore) 81(4):270 280. https://doi.org/10.1097/00005792-200207000-00003

12. Shiboski CH, Baer AN, Shiboski SC et al (2018) Natural HIstory and predictors of progression to Sjögren's syndrome among participants of the Sjögren's international collaborative clinical alliance registry. Arthritis Care Res (Hoboken) 70(2):284-294. https://doi.org/10.1002/acr.23264

13. García-Carrasco M, Mendoza-Pinto C, Jiménez-Hernández C, Jiménez-Hernández M, Nava-Zavala A, Riebeling C (2012)
Serologic features of primary Sjögren's syndrome: clinical and prognostic correlation. Int J Clin Rheumtol 7(6):651-659. https ://doi.org/10.2217/ijr.12.64

14. Shiboski CH, Shiboski SC, Seror R et al (2017) 2016 American College of Rheumatology/European League Against Rheumatism classification criteria for primary Sjögren's syndrome. Ann Rheum Dis 76:9-16. https://doi.org/10.1136/annrheumdis-2016210571

15. Wiersinga WM (2018) Hashimoto's thyroiditis. In: Vitti P, Hegedüs L (eds) Thyroid diseases. Endocrinology. Springer, Cham, pp 205-247 online ISBN 978-3-319-45013-1 https://doi. org/10.1007/978-3-319-45013-1_7

16. Maslinska M, Zuk-Wasek A (2015) Not only Sjögren's syndrome. EBV infection reactivation as a risk factor of the dryness symptoms development [abstract]. Arthritis Rheumatol. 67 (suppl 10). https://acrabstracts.org/abstract/not-only-sjogrens-syndromeebv-infection-reactivationas-a-risk-factor-of-the-dryness-sympt ome-development/. Accessed 25 Nov 2019 PMID: 26540142 doi: 10.1002/art.39448

17. Nagata K, Hara S, Nakayama $Y$ et al (2018) Epstein-barr virus lytic reactivation Induces IgG4 production by host B lymphocytes in graves' disease patients and controls: a subset of graves' disease is an IgG4-related disease-like condition. Viral Immunol 31(8):540-547. https://doi.org/10.1089/vim.2018.0042

18. Szczawinska-Poplonyk A, Wojsyk-Banaszak I, Jonczyk-Potoczna K et al (2016) Pulmonary manifestation of immunoglobulin G4-related disease in a 7-year-old immunodeficient boy with Epstein-Barr virus infection: a case report. Ital J Pediatr 42:58. https://doi.org/10.1186/s13052-016-0269-0

19. Lubbers R, van Essen MF, van Kooten C, Trouw LA (2017) Production of complement components by cells of the immune system. Clin Exp Immunol 188(2):183-194. https://doi.org/10.1111/ cei. 12952

20. Kawa S (2017) The Immunobiology of Immunoglobulin G4 and complement activation pathways in IgG4-related disease. Curr Top Microbiol Immunol 401:61-73. https://doi. org/10.1007/82_2016_39

21. Chen Z, Koralov SB, Kelsoe G (2000) Complement C4 inhibits systemic autoimmunity through a mechanism independent of complement receptors CR1 and CR2. J Exp Med 192:1339-1352. https://doi.org/10.1084/jem.192.9.1339

22. Wallace ZS, Deshpande V, Mattoo H et al (2015) IgG4-Related disease: clinical and laboratory features in one hundred twentyfive patients. Arthritis Rheumatol 67(9):2466-2475. https://doi. org/10.1002/art.39205

23. Fukui S, Fujita Y, Origuchi T et al (2019) Serum complement factor C5a in IgG4-related disease. Ann Rheum Dis 78:e65. https ://doi.org/10.1136/annrheumdis-2018-213705

24. Mavragani CP, Fragoulis GE, Rontogianni D, Kanariou M, Moutsopoulos HM (2014) Elevated IgG4 serum levels among primary Sjögren's syndrome patients: do they unmask underlying IgG4related disease? Athritis Care Res (Hoboken) 66(5):773-777. https://doi.org/10.1002/acr.22216

Publisher's Note Springer Nature remains neutral with regard to jurisdictional claims in published maps and institutional affiliations. 